\title{
Is tourism and hospitality education supporting Sustainability?
}

\author{
Galina Berjozkina \\ Department of Hospitality and Tourism, City Unity College Nicosia, Nicosia, Cyprus \\ Yioula Melanthiou \\ Department of Marketing, School of Business, University of Nicosia, Nicosia, Cyprus
}

\begin{abstract}
Purpose - Education can provide learners with the necessary awareness, values, and skills about the complexity of sustainability. The current study aims to analyse to what extent sustainability concepts have been implemented in higher education programs in the tourism and hospitality fields.

Design/methodology/approach- For the purpose of the current study, data on all tourism and hospitality programs offered in Cyprus higher education institutions at the Bachelors level was obtained. Analysis was conducted on publicly available program descriptions, learning outcomes, program content, syllabi and course descriptions.

Findings - The study finds that sustainability concept implementation in the undergraduate hospitality and tourism degree programmes are at the developing stage. The majority of the HEI follow trends and offer sustainability courses either as compulsory or elective courses, but concept implementation in program learning outcomes and program descriptions is shallow.

Originality/value - The paper presents a review of data and evidence on sustainability concept implementation in tourism and hospitality education in Cyprus.

Keywords - Education, Hospitality, Tourism, Sustainability, Sustainable tourism.

Paper type - Review of data/evidence
\end{abstract}

\section{Introduction}

According to the World Tourism Organization, tourism and hospitality, as the world's largest and fastest-growing industry, directly or indirectly employs 1 in 10 people. To serve the dynamic needs of the industry, education that prepares qualified, skilled professionals is one of the critical factors. Hospitality education has evolved in Switzerland over a century ago and was introduced in the USA and UK after the 1970s (Zopiatis \& Constanti, 2007). Tourism and hospitality higher education is developed from a very vocational perspective with a permanent industry presence and practical training (Airey \& Tribe, 2000). Moreover, while it was mainly hotel, accommodation and catering titled degrees in the 1990s, it has rapidly changed to use the term "Hospitality" in the degree titles (Nailon, 1981). Once program recognition took place, tourism and hospitality degree programs spread worldwide at a fast rate. Currently, tourism and hospitality degree programs are offered at vocational, diploma, bachelor, master and $\mathrm{PhD}$ levels around the globe.

The competitiveness of the hospitality and tourism industry in Cyprus has risen rapidly in recent years. Tourism has always contributed to Cyprus's economy, directly and indirectly, as $20 \%$ of the Country's GDP. Being a top-rated tourist destination over the last three decades, Cyprus, drawing more than 2.5 million visitors each year (Antonaras, 2018), needs qualified hospitality and tourism graduates every year. There were 57 public and private institutions in the academic year 2018/2019 with a total enrollment of 50.211 students, compared to 55 HEI with 47.169 enrolments in 2017/2018. Majority of the students $(73 \%)$ study in private universities. International students have risen significantly, reaching 27.388. The majority of the students graduate from business and administration (32\%), education (24\%), and social and 
behavioural science (6\%) fields (Statistical Service, 2021). It concludes that business administration studies were and continue to be the most popular HE field in Cyprus, including tourism and hospitality management studies. Tourism and hospitality education was first offered in Cyprus by the public institution Higher Hotel Institute of Cyprus, established in 1965. Since then, tourism and hospitality education has rapidly expanded in Cyprus, and currently, HEI, such as colleges, institutes, and universities, offer education in tourism and hospitality.

Thousands of individuals at all levels in higher education institutions worldwide have begun to consider sustainability as a fundamental component in education for sustainable development during the last few decades (Valezquez et al., 2005). In response, the United Nations has announced the United Nations Decade of Education for Sustainable Development (Boley, 2011) in 2005. The overall goal was to promote sustainable development in education worldwide and incorporate sustainable development concepts, values, and practices into all aspects of education and learning to solve the social, economic, cultural, and environmental challenges of the twenty-first century (Liimatainen, 2013). Nowadays, while acquiring industry-relevant skills, it is also essential to include critical thinking skills, particularly those connected to sustainability (Schweinsberg et al., 2013), in the curricula of tourism and hospitality degree programs. HEI in Cyprus has the challenge of addressing developments in the global tourism and hospitality education and program competitiveness on an international scale. Therefore, the particular research focuses on providing data and evidence regarding the implementation of sustainability concepts in tourism and hospitality education in Cyprus. In particular, the authors analysed how sustainability concepts are implemented in the overall program description and learning outcomes, program content and syllabi and course descriptions in tourism and hospitality education at the Bachelor level.

\section{How can education support sustainability efforts?}

In a worldwide effort to achieve economic, social and environmental sustainability, it is crucial to learn about sustainability (Liu et al., 2017). Education is of utmost importance, as it equips learners with values, knowledge, skills, and motivation (Sterling, 2010), so initiatives to be more sustainable can be adopted in private and professional life. There are two critical processes- cognition (to raise the awareness of sustainability and its complexity) and action (implying implementation methods and measures), which work together (Farber Canziani et al., 2012). In tourism education, sustainable tourism, with its variations, has been broadly taught within all tourism degree programs (Ruhanen \& Bowles, 2020). Still, as Boyle et al. (2015) emphasised, two paradigms exist when implementing sustainability within the curriculum of tourism degrees. A weak approach, which features a shallow view where sustainability is attached without holistic and critical analysis, and a robust approach, promoting an ecological view of education, holistically implementing sustainability within teaching and learning. Research on university programs in Australia found insufficient evidence that sustainability in education has taken a robust approach, and comprehensive sustainability-related views are merged in the curriculum (Boyle et al., 2014).

While many institutions currently provide sustainability curriculum and many more desire to do so, there is a shortage of information on what helps or inhibits such implementation (Weiss, Barth, Wiek, et al., 2021). According to Boyle et al. (2014, 2015), there are several reasons for the shallow perspective of sustainability in tourism education: resistance, lack of support, overcrowded curricula, and the fact that tourism schools, on many occasions, belong to more consumer-oriented business schools and faculties. Nevertheless, this is clear: "simply describing sustainability issues and suggesting alternative tourism forms will not achieve sustainability" (Benckendorff \& Moscardo, 2015). Therefore, education curricula should move beyond simply placing "sustainability" as a single course, hoping that students can grasp the 
issue's complexity in a single exam or essay. Instead, it should focus on "equipping learners with the necessary skills that will enable them to take positive actions toward addressing a range of sustainability issues, while also challenging them to consider what it means to be global citizens who enact sustainable principles as part of a lifelong learning process" (Ruhanen \& Bowles, 2020).

\section{Methodology}

The current study is a review of data and evidence to explore the implementation of sustainability concepts in tourism and hospitality education in Cyprus. For the purpose of this study, first, the description of the higher education system in Cyprus and a list of all registered institutions was obtained from the Cyprus Ministry of Education, Culture, Sport and Youth. The second step involved revising all HEI to select those that offer tourism and hospitality education at the Bachelors level. Institutions that are offering UK degrees in Cyprus were excluded from the analysis (e.g. University of Central Lancashire). Total 11 institutions were then included in the study - one public and two private universities and eight non-university level private institutions.

Further, publicly available information on 14 tourism-related BA programs offered by HEI was obtained from the official websites of each institution. Researchers then analysed each program, its description, content, syllabus, learning outcomes and other information provided by HEI. A summary of the results is presented in the following chapters.

\section{Tourism and hospitality education in Cyprus}

Higher education is offered by various higher institutions - including English-speaking public and private universities and colleges - at certificate, diploma, bachelor's and master's levels. The Bachelor's degree studies' estimated length is four years (eight semesters). The ECTS (European Credit Transfer and Accumulation System) is implemented by public and private universities, with at least 240 ECTS necessary for students to graduate (one credit unit equivalent to 25-30 working hours per semester).

Curriculum. The university level's shape and existence shall be determined by the Departmental Board of the University engaged and approved by the Senate and University Council (Ministry of Education and Culture, 2016). Private non-university institutions submit their courses and curriculum for approval to the Council of Educational EvaluationAccreditation.

Teaching Methods. Classes typically take the form of lectures, tutorials or practical work, and one institution is offering a distance learning BA degree.

Employability. Promoting the employability of graduates of higher education is a policy priority for the country. The Job Placement Program for Young Unemployed Tertiary Education Graduates in Enterprises/Organisations seeks to give both young graduates the ability to obtain work experience and companies the opportunity to build a healthy professional workforce (European Centre for the Development of Vocational Training (Cedefop), 2012). Career offices operating in HEI offer information on jobs and career opportunities. While the universities have no formal responsibility for the positions of their graduates, the recommendations and advice given have most contributed to the placement of graduates in suitable roles in their profession in the public or private sectors. HEI collaborates with associations in Cyprus (e.g. Cyprus Hotel Association, Cyprus Sustainable Tourism Initiative), public and private establishments to ensure the career development of tourism students.

Public universities. These HEI are founded as public, corporate bodies to be academically autonomous, governed by their Council and Senate. The government funds them, but they can raise money from other sources as well. There are three public HEI in Cyprus, of which one offers a BA degree: 
- The Cyprus University of Technology, Faculty of Management and Economics, Department of Hotel and Tourism Management, BA degree in Hotel Management and Tourism.

Private Universities. Private universities are founded as private law institutions of a theoretical or non-speculative nature registered with the Ministry of Education. Private universities in Cyprus were recently established- the House of Representatives adopted Law 109(I)/2005 on the creation and service of private universities in Cyprus (NOMO $\Sigma$ XE $\Delta \mathrm{IO}$ TIT $\Lambda$ ООРОYMENO, 2005). The legislation entered into effect on 29 July 2005. The first private universities in Cyprus started to work after a vote of the Council of Ministers on 12 September 2007. There are 1 UK university branch and five local universities, of which a BA degree in tourism is offered in:

- European University Cyprus, School of Business Administration, Department of Management and Marketing, BA in degree in Hospitality and Tourism Management;

- The University of Nicosia, School of Business, Department of Hospitality, Tourism and Sports Management, BA degree in Hospitality Management with concentrations in Casino Management and Spa and Wellness Centre Management; and BA degree in Tourism, Leisure and Events Management, BA degree in Hospitality Management (distance learning).

Non-university level public institutions. These HEI operate under the Ministry of Education and Culture. There are six institutions, of which none offer a BA degree in tourism.

Non-university level private institutions. These HEI are registered with the Ministry of Education and Culture, which provide for their establishment, operation and regulation. There are currently 32 institutions operating, of which 8 offer BA degrees in tourism (or related field):

- AC American College, BA in Travel and Tourism Management and BA in Hotel Management;

- Casa College, BA in Hotel Administration;

- City Unity College Nicosia, Hospitality Department, BA in International Hospitality and Tourism Management;

- C.D.A. College, Department of Travel and Tourism, B.A. (Hons) in Travel and Tourism Management;

- College of Tourism \& Hotel Management, BA in Hospitality Management;

- InterNapa College, BA in Hospitality \& Tourism Management;

- Larnaca College, Department of Hospitality and Tourism Management, BA in Hospitality \& Tourism Management;

- CTL EuroCollege, BA in Hotel Management.

Overall, tourism education is offered in different types of educational institutions in Cyprus- public and private universities and colleges. There are a total of 11 HEI offering BA degrees in Tourism and Hospitality related fields.

\section{Sustainability in tourism and hospitality education curricula in Cyprus}

Overall, $11 \mathrm{HEI}$ and 14 tourism-related BA programs were included in the analysis. One common trend is that at the university level, tourism education is offered under the Faculty / School of Business or Economics. In contrast, at the College level, it is narrow and, in some cases, a dedicated department that deals with tourism, hospitality, and travel are established. However, most commonly, Colleges do not have a departmental structure; instead, it is structured based on programs or levels of education (e.g. Diploma, BA, MA). The degree title structure summary is presented in Table 1. 


\begin{tabular}{|l|l|}
\hline \multicolumn{1}{|c|}{ Keywords in the program title } & Frequency \\
\hline Tourism management & $6(25 \%)$ \\
\hline Tourism & $3(13 \%)$ \\
\hline Hospitality management & $3(13 \%)$ \\
\hline Hotel management & $3(13 \%)$ \\
\hline Hospitality & $2(8 \%)$ \\
\hline Travel & $2(8 \%)$ \\
\hline International hospitality & $1(4 \%)$ \\
\hline Hotel administration & $1(4 \%)$ \\
\hline Leisure & $1(4 \%)$ \\
\hline Events management & $1(4 \%)$ \\
\hline Sports management & $1(4 \%)$ \\
\hline
\end{tabular}

The majority of the degrees offered are concentrated on Tourism Management and Tourism (a total of 38\%). Another focus is on Hospitality and Hotel Management (a total of $34 \%$ ). Several other niche degrees are offered, such as Leisure, Events, Sports Management. The further analysis concentrates on the degree program structure.

Chen and Groves (1999) present three models on philosophical relationships between Tourism and Hospitality curriculum. In one perspective, tourism and hospitality fields are symbiotic. Because of the uniqueness of each of the disciplines, they can both achieve more together, rather than separately. In Cyprus, HEIs tend to offer both Tourism and Hospitality in the degree title (e.g. European University of Cyprus, InterNapa College). In the second perspective, hospitality is in a dominating position, and tourism is seen as the travel sector (Chen \& Groves, 1999). Some HEIs in Cyprus, following this perspective, offer degrees in Hospitality management and administration (e.g. Casa College, College of Tourism \& Hotel Management). In the third and final philosophical perspective, tourism is in a dominant position and is seen as a system, where hospitality is only one segment of the system (Chen \& Groves, 1999). Following this perspective, American College and CAD College provide degrees in Travel and Tourism Management. An interesting approach is taken by the University of Nicosia, which separates the two in Degree in Hospitality Management and Degree in Tourism, Leisure and Events Management.

Evan et al. (2017) believe that the specifics of embedding sustainability are transferable to other cross-cutting educational priorities and, as a result, may be helpful to teacher educators working across and outside the mainstream subject boundaries that continue to shape the frame of the majority of teacher education programs (Evans et al., 2017). Other researchers state that sustainability is fundamentally interconnected and this approach "...suggests an education that aims to critically reflect and transcend by integrating classic dichotomies typically employed in scientific thought and education, such as nature-culture, local-global, and individualsocial. "(Salovaara et al., 2021)

In recent years tourism industry practitioners have turned their attention to the importance of sustainability. Sustainability policies and take precautions are being developed 
in many countries on spatial and institutional levels to ensure that cities use resources correctly and efficiently (Karadeniz et al., 2021). The hospitality industry has always had a significant environmental effect due to energy and water consumption, the usage of consumable and durable products, and the generation of solid and hazardous waste. Also, hotels that use energy are being used for lighting, power, and water for different departments and operations in the hotel, such as laundry, cleaning, and maintenance. Moreover, an inflow of tourists in a particular destination can disturb cultural and social processes and lead to economic inequalities. With environmental, socio-cultural, and economic harm the industry creates, it is essential to analyse whether future tourism professionals gain enough knowledge on sustainability during their education to implement more sustainable practices in their workplaces.

Considering the weak and strong sustainability implementation based on Boyle et al. $(2014,2015)$ classification and perspective from Flohr (2001), that "adequate response from the education sector should be to incorporate sustainable core units into the broad range of all courses on offer, rather than confining the sustainability debate just to specially designed sustainable tourism courses", authors first analysed sustainability concept implementation in the overall program description and learning outcomes.

In 14 degree programs, 6 has sustainability incorporated in the overall program description and learning outcomes. For example, European University of Cyprus: "...as well as destination planning and sustainable development, event organisation and international marketing strategies"; Larnaca College: "understand and address socioeconomic, cultural and environmental issues relevant to managing hospitality and tourism operations". At the College level, it is more common than the sustainability aspect is not directly incorporated into program description and aims but is mentioned indirectly. For example, American College: "To provide a broad view of tourism and the opportunity to explore issues and problems relevant to a wide range of situations and aspects likely to be faced by managers"; CTL Euro College: "analyse and evaluate contemporary issues within the areas of hotel management".

For further analysis, the program content, syllabi and course descriptions were considered. Courses that directly deal with sustainability were first identified. In the further steps, courses that indirectly deal with sustainability were found using search for keywords of sustainability economic, social and environmental dimensions. The findings of this analysis are summarised in Table 2.

Table 2

Sustainability courses within the BA degree curriculum

\begin{tabular}{|l|l|l|l|}
\hline \multicolumn{1}{|c|}{ Name of HEI } & \multicolumn{1}{|c|}{ Programme } & \multicolumn{1}{c|}{$\begin{array}{c}\text { Sustainability } \\
\text { courses }\end{array}$} & $\begin{array}{c}\text { Courses related to sustainability } \\
\text { dimensions }\end{array}$ \\
\hline $\begin{array}{l}\text { Cyprus University } \\
\text { of Technology }\end{array}$ & $\begin{array}{l}\text { BA degree in Hotel } \\
\text { Management and } \\
\text { Tourism }\end{array}$ & $\begin{array}{l}\text { Sustainable } \\
\text { Tourism } \\
\text { development }\end{array}$ & None \\
\hline $\begin{array}{l}\text { European } \\
\text { University of } \\
\text { Cyprus }\end{array}$ & $\begin{array}{l}\text { BA in degree in } \\
\text { Hospitality and } \\
\text { Tourism } \\
\text { Management }\end{array}$ & $\begin{array}{l}\text { Sustainable and } \\
\text { Responsible } \\
\text { Tourism }\end{array}$ & None \\
\hline $\begin{array}{l}\text { University of } \\
\text { Nicosia }\end{array}$ & $\begin{array}{l}\text { BA degree in } \\
\text { Hospitality } \\
\text { Management } \\
\text { (concentrations) }\end{array}$ & None & $\begin{array}{l}\text { Environmental Management for } \\
\text { Sourism and Hospitality } \\
\text { Society and Environment }\end{array}$ \\
\hline
\end{tabular}




\begin{tabular}{|c|c|c|c|}
\hline & $\begin{array}{l}\text { BA degree in } \\
\text { Tourism, Leisure } \\
\text { and Events } \\
\text { Management }\end{array}$ & $\begin{array}{l}\text { Sustainable } \\
\text { Tourism }\end{array}$ & $\begin{array}{l}\text { Environmental Management for } \\
\text { Tourism and Hospitality } \\
\text { Society and Environment }\end{array}$ \\
\hline & $\begin{array}{l}\text { BBA in Hospitality } \\
\text { Management }\end{array}$ & None & $\begin{array}{l}\text { Business Ethics, Environment and } \\
\text { CSR }\end{array}$ \\
\hline \multirow[t]{2}{*}{$\begin{array}{l}\text { AC American } \\
\text { College }\end{array}$} & $\begin{array}{l}\text { BA in Travel and } \\
\text { Tourism } \\
\text { Management }\end{array}$ & $\begin{array}{l}\text { Sustainable } \\
\text { Tourism }\end{array}$ & None \\
\hline & $\begin{array}{l}\text { BA in Hotel } \\
\text { Management }\end{array}$ & None & None \\
\hline Casa College & $\begin{array}{l}\text { BA in Hotel } \\
\text { Administration }\end{array}$ & None & None \\
\hline $\begin{array}{l}\text { City Unity } \\
\text { College Nicosia }\end{array}$ & $\begin{array}{l}\text { BA in International } \\
\text { Hospitality and } \\
\text { Tourism } \\
\text { Management }\end{array}$ & $\begin{array}{l}\text { Sustainable } \\
\text { Tourism } \\
\text { Sustainability for } \\
\text { Change }\end{array}$ & None \\
\hline C.D.A. College & $\begin{array}{l}\text { B.A. (Hons) in } \\
\text { Travel and Tourism } \\
\text { Management }\end{array}$ & $\begin{array}{l}\text { Sustainability in } \\
\text { Tourism }\end{array}$ & None \\
\hline $\begin{array}{l}\text { College of } \\
\text { Tourism \& Hotel } \\
\text { Management }\end{array}$ & $\begin{array}{l}\text { BA in Hospitality } \\
\text { Management }\end{array}$ & None & None \\
\hline InterNapa College & $\begin{array}{l}\text { BA in Hospitality } \\
\& \text { Tourism } \\
\text { Management }\end{array}$ & $\begin{array}{l}\text { Sustainability in } \\
\text { Hospitality \& } \\
\text { Tourism }\end{array}$ & None \\
\hline Larnaca College & $\begin{array}{l}\text { BA in Hospitality } \\
\text { \& Tourism } \\
\text { Management }\end{array}$ & $\begin{array}{l}\text { Sustainable } \\
\text { Tourism }\end{array}$ & Tourism, Heritage \& Society \\
\hline CTL EuroCollege & $\begin{array}{l}\text { BA in Hotel } \\
\text { Management }\end{array}$ & None & Society \& Environment \\
\hline
\end{tabular}

Learning about sustainable subjects helps to enhance one's overall and coherent thinking. Integrating sustainability into courses and putting it into reality is equally essential, especially in the case of sustainable tourism; these courses substantially reevaluate students' commitment to sustainable development (Ali and Bulcsú, 2021). In Cyprus, 8 out of 14 programmes offer a course that has the term "sustainability" in the course title, indicating that it is directly related to the term. Interestingly, in these cases, the courses are dealing with tourism or the tourism and hospitality industry. According to Inui et al. (2006), sustainable tourism is a common curriculum topic in HEI tourism and hospitality degree programs, which is also evident in Cyprus. In 5 out of 14 programs, some courses are not directly named with "sustainability" in the title but are related to environmental, socio-cultural or economic dimensions. 
The authors also conclude that general sustainability courses are not offered in tourism and hospitality programs. With general sustainability courses here, we mean that students do not have a course that deals with economic, environmental and socio-cultural principles in general, without application in the tourism and hospitality industry. This is how programs are organised at the Cyprus University of Technology and the European University of Cyprus. Knowing that universities are industry leaders in Cyprus and setting an example for others, similar programs are organised in five other colleges.

However, there are exceptions, for example, City Unity College Nicosia, that offers a course "Sustainability for Change" along with a "Sustainable Tourism" course, where students have a chance to learn general sustainability principles and then transition into sustainability applications in the tourism industry. A similar trend is observed in other institutions, too. For example, the University of Nicosia BA degree in Tourism, Leisure and Events Management offers a course "Sustainable Tourism" along with two more general courses that are not directly titled as sustainability courses, but are related to the term, namely "Environmental Management for Tourism and Hospitality" and "Society and Environment". Similarly, in Larnaca College, "Sustainable Tourism" is offered alongside the course "Tourism, Heritage \& Society". While more is not necessarily better, considering the complexity of the term, this could be an approach to provide a solid foundation on sustainability, as students would have the general theoretical knowledge alongside industry applications.

However, there are also HEI institutions that do not offer any sustainability or related courses. In Cyprus HEI, a "Sustainable Tourism" course is mainly offered in tourism management programs, while it is omitted in hospitality and hotel management/administration programs. This seems quite ironic, taking into account the environmental, social and economic harm that hotels and the hospitality industry create, e.g. water and air pollution, destruction of natural landscape etc. Future hotel managers should be familiar with sustainability concepts to implement significant changes leading to a more sustainable industry.

There is a potential for the HEI in Cyprus to look at the neighbouring countries and take their experience as an example. Adding new and modifying existing courses about sustainability will help students know the trends currently affecting the tourism and hospitality industry and prepare them as future managers and decision-makers.

\section{Conclusions}

Unlike few other sectors, tourism has experienced continuous expansion and diversification over the past six decades, emerging as one of the world's most significant and fastest-growing economic sectors. In recent years, interest in sustainable tourism has increased. International projects and research in sustainable tourism are designed to make this direction popular within academia. They include the discipline of the relevant field in hospitality and tourism-related educational programs. The implementation of sustainable development education at higher education institutions is essential to support the transition to sustainable development (Weiss, Barth and von Wehrden, 2021). In HE in Cyprus, sustainability is still an underdeveloped concept. Not all the universities and colleges in Cyprus that offer tourism and hospitality related Bachelor programmes offer sustainability courses as a required course. Sustainability courses in some HEI in Cyprus are provided as elective courses.

In some cases, these courses are replaced with something similar to sustainability, for example, society and environment courses. The description of the sustainability courses in some HEI is not always clear. We can only predict what this course will be about and what if we will learn sustainability concepts and procedures by taking this course. It can be said that Hospitality and Tourism Management BA programmes did not fully incorporate sustainability in their degree programmes; We can see that there are BA degrees with several pathways, but none of which 
is Sustainable Tourism. To become a more sustainable country and develop a more sustainable industry such as tourism and hospitality, Cyprus needs to place more considerable effort to incorporate sustainability into education at all levels. Knowing the above, we can indeed say that sustainability education in higher education is a critical lever for developing graduates' talents and knowledge to handle the linked social, ecological, and economic issues of the twenty-first century in their professional and personal life (Holdsworth and Sandri, 2021). It can ensure that the students will get the knowledge and awareness of sustainable hospitality and tourism practices to make significant changes in the industry.

In terms of limitations in the present study, the research was limited to one geographical area and the current state of the undergraduate programmes. Currently, Universities and Colleges in Cyprus do not offer the amount needed for courses that are related to sustainability. This may result in students not being familiar with specific trends and issues in the tourism and hospitality industry when they graduate and start their professional work.

Suggestions for future research is to explore Tourism and Hospitality offered programmes in Educational institutions in Cyprus without limiting them to just undergraduate studies but to take diploma and postgraduate studies and conduct a needs analysis. This will help to understand the state of HEI programmes and precisely the sustainability approach in higher education. Sustainability courses need to become a central part of undergraduate tourism and hospitality programmes because undergraduate students will work in the industry in Cyprus after their graduation and address sustainability in a much larger framework.

\section{References}

Airey, D., Dredge, D. and Gross, M.J., 2014. Tourism, hospitality and events education in an age of change (pp. 35-46). Routledge.

Antonaras, A. (2018), "The Cyprus Tourism Sector and the Sustainability Agenda 2030", The Cyprus Review, Vol. 30 No. 2, pp. 123-140.

Benckendorff, P. and Moscardo, G., 2015. Education for sustainability futures. In Education for Sustainability in Tourism (pp. 271-283). Springer, Berlin, Heidelberg.

Boley, B. B. (2011). Sustainability in hospitality and tourism education: Towards an integrated curriculum. Journal of Hospitality \& Tourism Education,23(4), 22-31.

Boyle, A., Wilson, E. and Dimmock, K., 2014. Space for Sustainability? Sustainable education in the tourism curriculum space. In The Routledge handbook of tourism and hospitality education (pp. 551-564). Routledge.

Boyle, A., Wilson, E. and Dimmock, K., 2015. Transformative education and sustainable tourism: The influence of a lecturer's worldview. Journal of Teaching in Travel \& Tourism, 15(3), pp.252-263.

Chen, K. and Groves, D., 1999. The importance of examining philosophical relationships between tourism and hospitality curricula. International Journal of Contemporary Hospitality Management, 11(1), pp.37-42. 


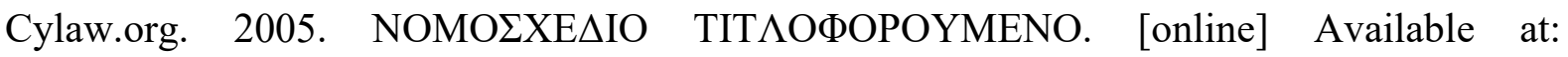
$<$ http://www.cylaw.org/nomoi/arith/2005_1_109.pdf> [Accessed 22 April 2021].

European Centre for the Development of Vocational Training (Cedefop), 2012. Vocational education and training in Cyprus. Short description. Luxembourg: Publications Office of the European Union, p.22.

Farber Canziani, B., Sönmez, S., Hsieh, Y. and Byrd, E.T., 2012. A learning theory framework for sustainability education in tourism. Journal of Teaching in Travel \& Tourism, 12(1), pp.320 .

Farber Canziani, B., Sönmez, S., Hsieh, Y. and Byrd, E.T., 2012. A learning theory framework for sustainability education in tourism. Journal of Teaching in Travel \& Tourism, 12(1), pp.320.

Higher Education in Cyprus. 2nd ed. [ebook] Nicosia: Press and Information Office, p.13. Available at: <http://www.highereducation.ac.cy/information_booklet/files/highereducationvivliaraki.pdf $>$ [Accessed 3 June 2021].

Inui, Y., Wheeler, D. and Lankford, S., 2006. Rethinking tourism education: What should schools teach? Journal of Hospitality, Leisure, Sport and Tourism Education, 5(2), pp.25-35. Liimatainen A. (2013) United Nations Decade of Education for Sustainable Development. In: Idowu S.O., Capaldi N., Zu L., Gupta A.D. (eds) Encyclopedia of Corporate Social Responsibility. Springer, Berlin, Heidelberg.

Liu, C.H., Horng, J.S., Chou, S.F. and Huang, Y.C., 2017. Analysis of tourism and hospitality sustainability education with co-competition creativity course planning. Journal of Hospitality, Leisure, Sport \& Tourism Education, 21, pp.88-100.

Liu, C.H., Horng, J.S., Chou, S.F. and Huang, Y.C., 2017. Analysis of tourism and hospitality sustainability education with co-competition creativity course planning. Journal of Hospitality, Leisure, Sport \& Tourism Education, 21, pp.88-100.

Ministry of Education and Culture, 2016. A guide to Education in Cyprus. Nicosia: CYPRUS PEDAGOGICAL INSTITUTE, pp.96-102.

Schweinsberg, S., Wearing, SL and McManus, P. (2013), "Exploring sustainable tourism education in business schools: The honours program", Journal of International Hospitality, Leisure \& Tourism Management, Vol. 20, pp. 53-60.

Statistical Service, 2021. STATISTICS OF EDUCATION 2018/2019. I. [online] Nicosia: Republic of Cyprus Ministry of Finance, pp.9-10. Available at: $<$ https://www.mof.gov.cy/mof/cystat/statistics.nsf/All/204AA86C4060D499C22577E4002C 
A3E3/\$file/EDUCATION-2018_2019-EN-310321.pdf?OpenElement> [Accessed 4 June 2021].

Sterling, S. ed., 2010. Sustainability education: Perspectives and practice across higher education. Taylor \& Francis.

Sterling, S. ed., 2010. Sustainability education: Perspectives and practice across higher education. Taylor \& Francis.

Velazquez, L., Munguia, N. and Sanchez, M., 2005. Deterring Sustainability in higher education institutions. International Journal of Sustainability in Higher Education, 6(4), pp.383-391.

Zopiatis, A. and Constanti, P., 2007. "And never the twain shall meet". Education + Training, 49(5), pp.391-407.

Ali, B. and Bulcsú, R. (2021), "The importance of environmental and sustainability education in tourism based on the opinion of students at Budapest Business School", Prosperitas, Budapesti Gazdasági Egyetem, Vol. 8 No. 1, pp. 4-22.

Evans, N. (snowy), Stevenson, R.B., Lasen, M., Ferreira, J.-A. and Davis, J. (2017), "Approaches to embedding sustainability in teacher education: A synthesis of the literature", Teaching and Teacher Education, Vol. 63, pp. 405-417.

Holdsworth, S. and Sandri, O. (2021), "Investigating undergraduate student learning experiences using the good practice learning and teaching for sustainability education (GPLTSE) framework", Journal of Cleaner Production, Vol. 311, p. 127532.

Karadeniz, B., Barut, M., Ünlü Öztürk, C. and Tatli, P. (2021), "Sustainability in urban and regional planning education in turkey", Eurasian Journal of Educational Research, Ani Publishing and Consulting Company, Vol. 21 No. 92, available at:https://doi.org/10.14689/ejer.2021.92.3.

Salovaara, J.J., Pietikäinen, J. and Cantell, H. (2021), "Perceptions of interconnected sustainability: Students' narratives bridging transition and education", Journal of Cleaner Production, Elsevier BV, Vol. 281 No. 125336, p. 125336.

Weiss, M., Barth, M. and von Wehrden, H. (2021), "The patterns of curriculum change processes that embed sustainability in higher education institutions", Sustainability Science, available at:https://doi.org/10.1007/s11625-021-00984-1. 
Weiss, M., Barth, M., Wiek, A. and von Wehrden, H. (2021), "Drivers and barriers of implementing sustainability curricula in higher education -- assumptions and evidence", Higher Education Studies, Canadian Center of Science and Education. 1595 Sixteenth Ave Suite 301, Richmond Hill, Ontario, L4B 3N9Canada. Tel: 416-642-2606; Fax: 416-642-2608; e-mail: hes@ccsenet.org; Web site: http://www.ccsenet.org/journal/index.php/hes, Vol. 11 No. 2, pp. 42-64. 